\title{
Tubular Biogas Digester Berbahan Buis Beton: Desain Konseptual, Potensi dan Analisa Ekonomi
}

\author{
Anatta Wahyu Budiman', Muhammad Cahyadi², Ahmad Pramono², Muchammad Yusuf Firdaus ${ }^{1}$, \\ Yazid Rizal Azinuddin ${ }^{1}$, Riki Agung Prasetya ${ }^{1}$, Sofian Pradipta Respati Saputra ${ }^{1}$ \\ ${ }^{1}$ Program Studi Teknik Kimia, Fakultas Teknik, Universitas Sebelas Maret, Jalan Ir. Sutami no 36A \\ Kentingan, Jebres, Surakarta 52716 \\ ${ }^{2}$ Program Studi Peternakan, Fakultas Pertanian, Universitas Sebelas Maret, Jalan Ir. Sutami no 36A \\ Kentingan, Jebres, Surakarta 52716 \\ *email: budiman@staff.uns.ac.id
}

\begin{abstract}
Biogas is becoming a main potential renewable energy resource that provides an environmentally friendly energy easily accessed by people in the rural area. So far, there are three main common concepts of biogas digester as the Fixed Dome biogas digester, the floating dome digester, and the Baloon Plastic digester. With their specific characteristics, the fixed dome and the balloon plastic digester are potential to be applied in Indonesia. In this work, the modification of fixed dome biogas digester concept using cylindrical concrete (buis beton) is introduced. This novel technology promises comparable strength and leaks free characteristics of fixed dome concept, with several benefits such as easier construction and more economical. A conceptual design toward economical aspects is presented in this manuscript.
\end{abstract}

Keywords: biogas, digester, buis beton.

\section{Pendahuluan}

Biogas merupakan salah satu energi alternatif yang ramah lingkungan. Dibandingkan dengan LPG yang beredar di pasaran, biogas memiliki rantai karbon yang lebih pendek sehingga mampu menghasilkan pembakaran yang lebih sempurna. Biogas sangat menjanjikan untuk berperan menjadi energi yang terbarukan karena dapat diperoleh dari air limbah rumah tangga, kotoran cair dari peternakan ayam, sapi, babi, sampah organik dari pasar, industri makanan, pabrik tapioka, pabrik kelapa sawit, sampah kota dan lainnya. Namun, hingga saat ini pemanfaatan biogas kurang dari satu persen dari potensi biogas yang ada [1].

Selain menjadi energi alternatif, biogas juga dapat mengurangi permasalahan lingkungan, seperti mengurangi jumlah polutan, mengurangi bau yang tidak sedap yang diakibatkan oleh sampah, mencegah penyebaran penyakit, serta memberikan hasil samping berupa pupuk padat dan cair. Praktek pertanian/ rumah tangga dengan instalasi biogas didalamnya mampu menjadi contoh pertanian ramah lingkungan yang menerapkan pertanian nir limbah (zero waste) dan pertanian berkelanjutan (sustainable agriculture) sehingga mewujudkan masyarakat yang lebih sehat dan berdaya ekonomi tinggi.

Proses anaerobic digestion untuk pembuatan biogas diawali sekitar tahun 1895 di Bombay, India dengan masukan berupa kotoran padat dari limbah rumah tangga dengan tujuan untuk penghasil energi bagi penerangan kota. Sementara di eropa, hingga saat ini terdapat lebih 600 biogas digester skala pertanian untuk menunjang kebutuhan energi yang semakin mahal dan menyiasati pencemaran lingkungan akibat proses pertanian. Di Indonesia sendiri, biogas sudah dikembangkan sejak tahun 1980-an. Namun, teknologi ini belum berkembang dengan baik karena kelimpahan lahan sehingga pembuangan kotoran masih bisa dilakukan di lahan kosong, kurangnya pengetahuan mengenai teknologi biogas, ketidakmampuan mengatasi kebocoran pada reaktor, biaya pembuatan masih mahal, serta masalah non teknis seperti perubahan pekerjaan dari petani menjadi pedagang atau pegawai negeri.

Secara teoretis, biogas merupakan hasil dari proses penguraian bahan-bahan organik (limbah) yang dilakukan oleh mikroorganisme dalam kondisi hampa udara (anaerob), untuk menghasilkan campuran dari beberapa gas, diantaranya metana dan $\mathrm{CO}_{2}$. Biogas dihasilkan dengan bantuan bakteri metanogen atau metanogenik. Bakteri ini secara alami terdapat dalam limbah yang mengandung bahan organik, seperti limbah ternak dan sampah organik. Proses tersebut dikenal dengan istilah anaerobic digestion atau pencernaan secara anaerob. Umumnya, biogas diproduksi menggunakan alat yang disebut reaktor biogas (digester) yang dirancang agar kedap udara (anaerob), sehingga proses penguraian oleh mikroorganisme dapat berjalan secara optimal [2]. Pada umumnya selain menghasilkan metana dan karbon dioksida, $\mathrm{H}_{2} \mathrm{~S}$ dan $\mathrm{NH}_{3}$ juga dihasilkan dalam jumlah yang tidak signifikan. 
Terdapat beberapa parameter teknis yang menunjang keberhasilan pembuatan biogas menggunakan teknologi Anaerobic digester ini antara lain:

- Proses pencampuran. Substrat berupa sampah basah ataupun kotoran hewan, harus dicampurkan dengan sejumlah air. Proses pencampuran ini meningkatkan kontak antara mikroba pengurai dan substrat sehingga proses penguraian berlangsung secara optimal. Pencampuran juga mencegah terjadinya proses digesting yang tidak merata.

- Temperatur. Temperatur sekitar $50-65{ }^{\circ} \mathrm{C}$ dibutuhkan oleh bakteri berjenis thermophilic untuk menguraikan substrat menjadi biogas. Sementara untuk penggunaan bakteri mesophilic, dibutuhkan rentang suhu yang lebih rendah sekitar 20-45 ${ }^{\circ} \mathrm{C}$. Pada umumnya kotoran hewan ternak sudah mengandung bakteri methanogen yang bersifat mesofilik [3].

- Derajat keasaman (pH). Proses digesting merupakan proses yang sensitif terhadap derajat keasaman. Dalam prosesnya, terdapat tiga tahapan yang dibutuhkan dalam digesting substrat menjadi biogas yakni tahap hidrolisis (penguraian senyawa kompleks menjadi senyawa sederhana), acidogenesis (pembentukan asam dari senyawa sederhana), dan methanogenesis (pembentukan metana dari asam lemak rantai pendek). Tahapan acidogenesis membutuhkan $\mathrm{pH}$ yang tinggi sementara $\mathrm{pH}$ diatas 6,4 berbahaya bagi bakteri yang berperan dalam tahapan methanogenesis. Sehingga $\mathrm{pH}$ optimal dari proses digesting adalah sekitar 6,4.

- Waktu tinggal. Waktu tinggal dibutuhkan untuk mendegradasi substrat untuk menjadi biogas secara sempurna. Waktu tinggal selama 15-20 hari dibutuhkan bakteri methanogen untuk menguraikan substrat yang ada.

- Rasio C:N. Rasio optimum pada pembentukan biogas melalui proses anaerobic digesting adalah antara 20-30. Rasio yang terlalu tinggi menyebabkan berkurangnya produksi gas akibat konsumsi nitrogen yang terlalu cepat, sementara rasio yang terlalu tinggi menyebabkan meningkatnya $\mathrm{pH}$ sehingga berbahaya bagi bakteri methanogen.

\section{Potensi biogas di Indonesia}

Limbah kotoran hewan seperti, sapi, kuda, kerbau dan babi, juga dijumpai di seluruh wilayah Indonesia. Biro Pusat Statistik menunjukkan data jumlah populasi sapi potong sebesar 12.329.477 ekor, kerbau sebanyak 1.085.450 ekor dan untuk populasi kambing sebanyak 13.491 .190 ekor [4]. Ditambah dengan potensi sampah rumah tangga, sampah pasar dan sampah-sampah organik lainnya, maka pengembangan biogas sangat potensial untuk diterapkan di Indonesia. Pada umumnya limbah pertanian dan limbah rumah tangga memiliki tingkat kesulitan yang lebih tinggi untuk diolah menjadi biogas dibandingkan dengan kotoran ternak, karena lebih lama waktu yang dibutuhkan untuk proses hidrolisis bahan selulosa dari limbah pertanian dan hara.

Dibandingkan dengan bahan bakar lain, biogas memiliki nilai kesetaraan yang cukup potensial dimana 1 $\mathrm{m}^{3}$ biogas setara dengan; elpiji 0,46 kg, 0,62 liter minyak tanah, 0,52 liter minyak solar, 0,80 liter minyak bensin, 1,50 $\mathrm{m}^{3}$ gas kota dan 3,50 kg kayu bakar [5]. Seekor sapi dewasa biasanya menghasilkan kotoran sebanyak $10 \mathrm{~kg}$ setiap harinya. Namun untuk sapi yang berbobot diatas rata rata, banyaknya kotoran bisa lebih dari $10 \mathrm{~kg}$ perharinya. Dengan asumsi setiap $1 \mathrm{~m}^{3}$ dihasilkan dari $20 \mathrm{~kg}$ kotoran sapi, maka setiap kilogram kotoran sapi mampu menghasilkan $0.045 \mathrm{~m}^{3}$ biogas. Biogas sejumlah ini mampu memberikan energi untuk memasak 1 liter air atau menanak nasi seberat $1 / 6 \mathrm{~kg}$. Apabila peternak mandiri memiliki sapi sebanyak dua lima ekor, maka kotoran yang dihasilkan mampu menyuplai energi untuk kebutuhan memasak.

\section{Perbandingan konsep Biogas Digester}

Terdapat tiga konsep umum dalam pembuatan biogas digester yakni konsep fixed dome digester, floating dome digester, dan baloon plastic digester (Gambar 1).

Fixed dome digester terdiri dari kolam penampung, tangki fermentor dan penampung sisa fermentasi. Ketika gas mulai timbul, gas tersebut menekan lumpur sisa fermentasi (slurry) keluar menuju penampung sisa fermentasi. Gas yang terbentuk kemudian disalurkan ke penampungan gas atau langsung dijadikan bahan bakar. Pada konsep digester ini tidak ada bagian yang bergerak sehingga instalasi dapat berumur panjang. Umumnya instalasi dibuat di dalam tanah sehingga terlindung dari berbagai cuaca atau gangguan lain. Namun demikian, karena tidak ada katup gas, tekanan didalam digester tidak stabil. Kelemahan lain dari tipe ini adalah kesulitan menemukan kebocoran karena instalasi dilakukan dengan menggunakan gabungan batu bata dan beton.

Floating drum digester terdiri dari satu digester dan penampung gas yang bisa bergerak. Penampung gas ini akan bergerak keatas ketika gas bertambah dan turun lagi ketika gas berkurang, seiring dengan 
penggunaan dan produksi gasnya. Dibandingkan dengan tipe fixed dome, tekanan gas lebih konstan karena penampung gas yang bergerak mengikuti jumlah gas. Jumlah gas yang terbentuk juga bisa dengan mudah diketahui dengan melihat naik turunya drum. Namun demikian umumnya tipe digester ini berumur pendek karena rentan terhadap korosi.

Baloon plastic digester adalah tipe digester dengan konstruksi paling sederhana, terbuat dari plastik yang pada ujung-ujungnya dipasang pipa masuk untuk kotoran ternak dan pipa keluar peluapan slurry. Sedangkan pada bagian atas dipasang pipa keluar gas. Tipe ini yang paing umum dipasang di indonesia karena kemudahan dan kemurahannya, namun demikian umur digester ini tidak panjang karena bahannya yang mudah mengalami kerusakan.

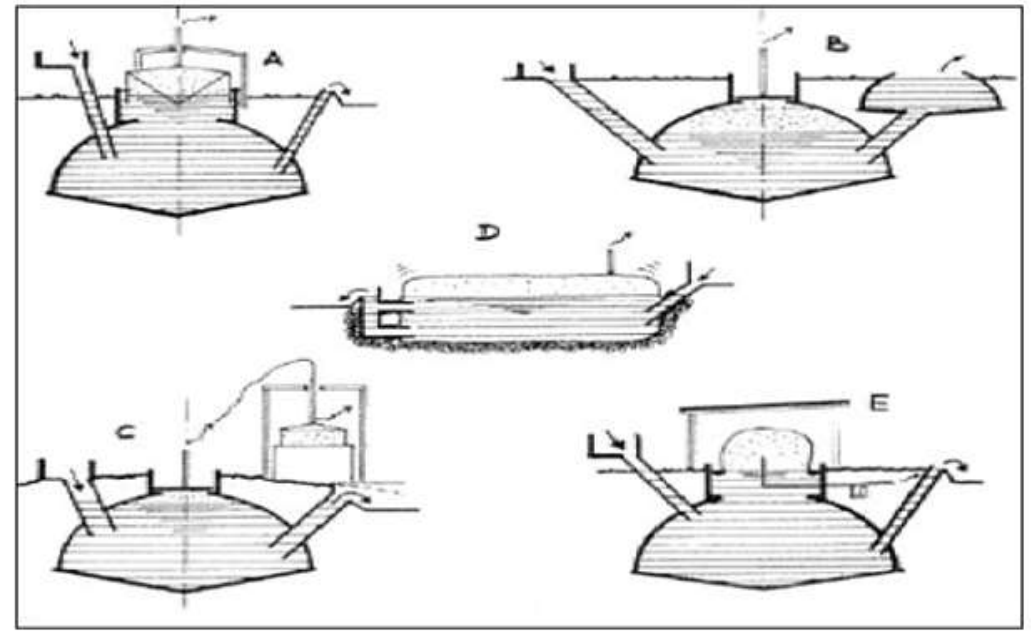

Gambar 1. Tipe biodigester: (a) Floating drum plant, (b) fixed dome plant, (c) fixed dome plant with gas holder terpisah, (d) baloon plant, (e) chanel-typed digester dengan pelindung matahari dan lapisan plastik [5]

\section{Metodologi Penelitian}

Pada tulisan ini kami mencoba mengkombinasikan konsep baloon plastic digester yang umumnya berbentuk silinder tidur, dengan konsep fixed dome digester yang berbahan beton. Buis beton yang umumnya digunakan untuk pembuatan sumur dan gorong gorong, digunakan untuk menggantikan plastik pada biogas digester bertipe Baloon plastic sehingga memiliki kekuatan dan ketangguhan bahan yang lebih baik (Gambar 2). Penggunaan buis selain harganya yang lebih ekonomis juga akan mempermudah dalam instalansi pembuatan biodigester tanpa mengurangi kualitas hasil gas yang diproduksi. Penggunaan buis sebagai material digester menggabungkan kebaikan baloon plastic berupa kemudahan instalasi, ketahanan bocor, dan harga yang murah dengan kebaikan fixed dome berupa kekuatan material. Pilihan lain dalam modifikasi biogas digester adalah menggunakan bahan fiberglass. Namun demikian pilihan bahan ini dinilai tidak sekuat beton. 


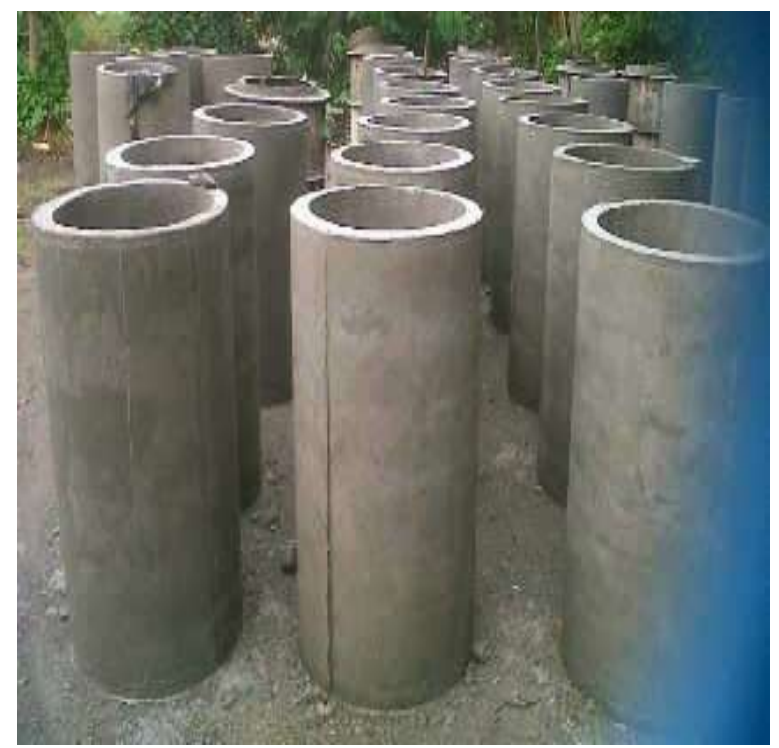

Gambar 2. Buis beton

\section{Hasil dan Pembahasan}

Konsep desain pada digester digambarkan oleh Gambar 3. bagian A merupakan bagian input yang berfungsi untuk memasukkan kotoran dan air kedalam digester. Pada bagian ini dilakukan pencampuran air dan substrat kotoran kotoran sapi dengan kombinasi tertentu serta dilakukan pula penyaringan bahan bahan yang tidak bisa ter-digest dalam biodigester seoperti jerami, tanah, dan sisa pakan.

Bagian B merupakan digestion tank yang berfungsi sebagai tempat fermentasi kotoran menjadi gas. Proses digestion terjadi selama kurang lebih dua pekan dengan menggunakan bakteri methanogen yang terkandung dalam kotoran sapi. Untuk menghindari kebocoran, buis beton dilapisi dengan lapisan semen dan cat pelapis anti bocor.

Bagian C merupakan output untuk pengeluaran kotoran setelah fermentasi. Seperti halnya konsep fixed dome, gas yang terbentuk di dalam digestion tank akan menekan sisa hasil fermentasi kearah tangki pengeluaran kotoran. Produk dalam tangki ini merupakan kotoran yang telah hilang gas-nya (sludge) yang bisa digunakan untuk pupuk cair berkualitas tinggi.

Bagian D adalah pipa pengeluaran gas hasil fermentasi kotoran untuk disalurkan ke kompor.

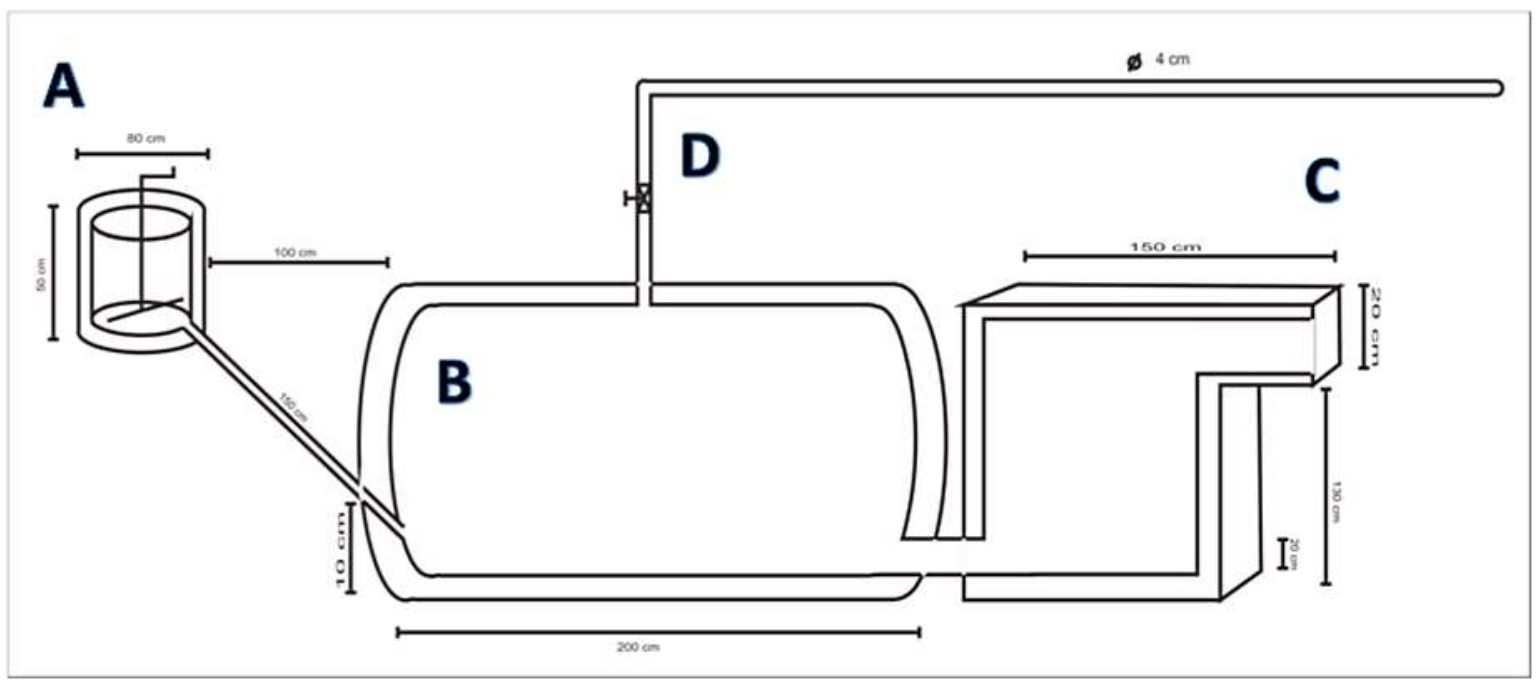

Gambar 3. Desain biogas digester berbahan buis beton 


\section{Analisa Ekonomi}

Dengan pemasangan biogas digester berbahan buis beton ini diperkirakan usia digester mampu mencapai minimal 20 tahun pemakaian. Dengan modal sekitar 5,4 juta rupiah (Tabel 1.), nilai penerimaan yang bersumber dari nilai substitusi LPG untuk kebutuhan rumah tangga (4 tabung/bulan ukuran $3 \mathrm{~kg}$ dengan harga $\mathrm{Rp} \mathrm{17.000/tabung)} \mathrm{dan} \mathrm{slurry} \mathrm{yang} \mathrm{dihasilkan} \mathrm{(20 \%} \mathrm{dari} \mathrm{total} \mathrm{kotoran} \mathrm{ternak} \mathrm{yang} \mathrm{digunakan} \mathrm{dengan}$ harga slurry Rp375/kg) diperoleh sebesar Rp2.166.000/tahun (Sumber kotoran ternak untuk digester dapat tercukupi dari skala pemeliharaan ternak sapi perah 2-3 ekor) [6]. Maka pembangunan Tubular Biogas digester berbahan Buis Beton ini layak dipertimbangkan untuk dipertimbangkan untuk dikembangkan di desa desa di Indonesia.

Tabel 1. Daftar harga material penyusun Tubular Biogas digester berbahan Buis Beton

\begin{tabular}{|c|c|c|c|c|c|}
\hline No. & Material & Justifikasi pemakaian & Kuantitas & $\begin{array}{c}\text { Harga } \\
\text { satuan (Rp) }\end{array}$ & $\begin{array}{c}\text { Jumlah } \\
\text { harga (Rp) }\end{array}$ \\
\hline 1. & Buis $80 \times 50$ & Tempat input bahan & 1 buah & 235.000 & 235.000 \\
\hline 2. & Buis $150 \times 50$ & Tempat fermentasi & 4 buah & 630.000 & 2.250 .000 \\
\hline 3. & Penutup buis 80 & Penutup buis & 1 buah & 80.000 & 80.000 \\
\hline 4. & Penutup buis 150 & Penutup buis & 4 buah & 150.000 & 300.000 \\
\hline 5. & Pipa karet 6 inch & Penyalur bahan ke biodigester & 4 batang & 100.000 & 400.000 \\
\hline 6. & Pipa pralon 1,5 inch & Penyalur gas ke kompor & 4 batang & 30.000 & 120.000 \\
\hline 7. & Gate valve & Pengatur aliran gas & 3 buah & 15.000 & 45.000 \\
\hline 8. & Batu bata & Konstruksi alat & 1000 buah & 700 & 700.000 \\
\hline 9. & Semen & Perekat alat & 4 sak & 45.000 & 180.000 \\
\hline 10. & Pasir & Campuran perekat alat & 1 colt & 300.000 & 300.000 \\
\hline 11. & Selang Transparan 0,5 inch & Alat manometer & 2 meter & 10.000 & 20.000 \\
\hline 12. & Penggaris besi $100 \mathrm{~cm}$ & $\begin{array}{l}\text { Pengukur ketinggian air } \\
\text { manometer }\end{array}$ & 1 buah & 10.000 & 10.000 \\
\hline 13. & Presure gauge & Pengukur tekanan & 1 buah & 75.000 & 75.000 \\
\hline 14. & Kompor gas 2 tungku & Alat penguji gas & 1 buah & 325.000 & 325.000 \\
\hline 15. & Sambungan elbow & Penyambung pipa & 5 buah & 15.000 & 75.000 \\
\hline \multirow[t]{2}{*}{16.} & Sambungan lurus & Penyambung pipa & 5 buah & 8.000 & 40.000 \\
\hline & & & & Total & 5.425 .000 \\
\hline
\end{tabular}

\section{Ucapan Terimakasih}

Tulisan ini merupakan hasil luaran dari program iptek bagi masyarakat PNBP-UNS dengan judul "Desa Mandiri Sampah dan Energi Berbasis Teknologi Pengolahan Kotoran Ternak dan Sampah Organik”

\section{Referensi}

[1] Badan Litbang Pertanian. 2011. Biogas Pembuatan Konstruksi, Operasional dan Pemeliharaan Instalasinya. Edisi 1-7 Juni 2011 No. 3408 Tahun XL1.

[2] Monnet, F. 2003. An introduction to anaerobic digestion of organic wastes. Remade Scotland, pp.1-48.

[3] A. Darmanto, S. Soeparman, dan D. Widhiyanuriawan. 2012. Pengaruh kondisi Temperatur mesophilic dan thermophilic Anaerob digester kotoran kuda terhadap produksi biomass" J. rekayasa mesin. Vol. 3, No. 2, p. 317.

[4] Badan Pusat Statistik. 2013. "Grafik Sensus Pertanian 2013 Indonesia".

[5] Sunaryo. 2014. "Rancang Bangun Reaktor Biogas untuk Pemanfaatan Limbah Kotoran Ternak Sapi di Desa Limbangan Kabupaten Banjarnegara” J. PPKM UNSIQ. vol. 1, pp. 21-30.

[6] Agustian, A. "Pengembangan Biogas Berbasis Kotoran Ternak Dalam Rangka Pemberdayaan Potensi Sumber Daya Peternakan Sapi Perah Di Jawa Barat" Membangun Daya Tahan Pertanian dalam Rangka Pemberdayaan Petani dan Perlindungan Pertanian. 